\title{
Introduction: Cormac McCarthy Between Worlds
}

James Dorson, Julius Greve and Markus Wierschem

\section{(2) OpenEdition \\ Journals}

Electronic version

URL: https://journals.openedition.org/ejas/12253

DOI: 10.4000/ejas. 12253

ISSN: 1991-9336

Publisher

European Association for American Studies

\section{Electronic reference}

James Dorson, Julius Greve and Markus Wierschem, "Introduction: Cormac McCarthy Between Worlds", European journal of American studies [Online], 12-3 | 2017, Online since 27 November 2017, connection on 08 July 2021. URL: http://journals.openedition.org/ejas/12253 ; DOI: https://doi.org/ 10.4000/ejas. 12253

This text was automatically generated on 8 July 2021.

Creative Commons License 


\title{
Introduction: Cormac McCarthy Between Worlds
}

\author{
James Dorson, Julius Greve and Markus Wierschem
}

Cormac McCarthy is one of the most celebrated writers today. Besides the many prizes that his fiction has garnered (including the National Book Award, the Pulitzer Prize, the National Book Critics Circle Award, and the McArthur "Genius Grant"), his work has also inspired a broad range of cultural spinoffs and homages from adaptations in film and music all the way to literary parodies and imitations of his style. Having been embraced across the cultural spectrum from Hollywood to Harold Bloom, his status as one of the most significant contemporary voices in American fiction is uncontested. But if there is an across-the-board cultural agreement that McCarthy is one of our great writers, the same cannot be said of the growing scholarly industry bent on understanding his work. In spite of monographs such as Steven Frye's Understanding Cormac McCarthy (2009), and numerous edited volumes, "companions," and "reader's guides" dealing with his novels, there is little agreement about how his work should be read. Is he a modernist or a late modernist writer, a postmodern or a post-postmodern one? Is his work political or apolitical, revisionist or traditionalist? Is it scientific or philosophical, theological or materialist, humanist or anti-humanist, pastoral, counterpastoral, or eco-pastoral?

2 All of these questions are still-and are likely to remain-unresolved, fuelling much critical debate both within and beyond the growing community of McCarthy scholars. As is the case with most writers now considered seminal contributors to American literary history, his work seems to have the rare ability to remain interesting and enigmatic no matter how much we critically dissect it-indeed, so fruitful and generative as to accommodate ever new and diversified critical approaches. Vereen Bell's assertion in the first monograph published on McCarthy's novels in 1988 that they "belligerently resist abstraction and classification" (2) is as true today as ever.

3 Part of the slipperiness of McCarthy's fiction has to do with how it bridges and combines contrasting styles and discourses. His work draws on scientific discourse yet resists positivism with every parable or outlandish simile. It challenges exceptionalist 
narratives of national innocence through its relentless violence but has characters like John Grady Cole in the Border Trilogy and the boy in The Road (2006), who are as innocent as they come. His literary worlds are composed of myths and legends but also of natural history and documented historical events, evoking frequently incommensurable philosophical, theological, and scientific traditions and ideas. His style oscillates between expansive lyricism and pared down minimalism. The list goes on. In fact, whatever we seem to say about McCarthy it seems possible to say the opposite.

$4 \quad{ }^{1}$ If we can never really pin down his work, then, it may be because it inhabits a space between various styles and discourses without being reducible to any one of them. In these respects and others, McCarthy certainly makes good on his own view of the novel as a framework suited to "encompass all the various disciplines and interests of humanity" (Woodward 30-1).

5 One of the aims of this special issue of The European Journal of American Studies is to examine and shed further light on the aesthetic and disciplinary fault lines and tensions that constitute McCarthy's fiction, which traverses other fictional and nonfictional worlds. Notwithstanding the expanding body of criticism on McCarthy, we claim that it is precisely the in-betweenness of irreconcilable worlds in his fiction that warrants further examination. The fifteen essays collected here examine Cormac McCarthy's fiction from a number of disciplinary and interdisciplinary perspectives that shed light on his work in terms of its negotiations of and investments in science, painting, music, theology, philosophy, politics, cinema, anthropology, economics, systems theory, genre fiction, and the novel form itself, to name but some of the approaches represented in this issue. Written by a mixture of first-time as well as longestablished McCarthy scholars based in seven different countries across three continents, the essays in this issue testify both to the global interest in McCarthy's work and to the continued vibrancy of the scholarship dedicated to it.

Bell, Vereen. The Achievement of Cormac McCarthy. Baton Rouge: Louisiana State UP, 1988. Print.

Woodward, Richard B. “Venomous Fiction." New York Times Magazine 19 Apr. 1992. Web. 13 Nov. 2017.

http://www.nytimes.com/1992/04/19/magazine/cormac-mccarthy-s-venomousfiction.html?pagewanted=all

\section{NOTES}

1. Christina Bieber Lake's theological reading of The Road and Patrick O'Connor's materialist reading of it in this special issue are a case in point. 
INDEX

Keywords: Cormac McCarthy

\section{AUTHORS}

\section{JAMES DORSON}

James Dorson is an assistant professor at the John F. Kennedy Institute for North American Studies, Freie Universität Berlin. He is the author of Counternarrative Possibilities: Virgin Land, Homeland, and Cormac McCarthy's Westerns (2016) and the co-editor of the special issue of Studies in American Naturalism titled “Data Fiction: Naturalism, Narratives, and Numbers." He has written essays on David Foster Wallace, Edith Wharton, Frank Norris, Jack London, and business culture in the Progressive Era. His research interests include critical theory, labor fiction, business history, and literature and economics. He is currently writing a book on naturalism and the spirits of capitalism at the turn of the twentieth century.

\section{JULIUS GREVE}

Julius Greve is a lecturer and research associate at the Institute for English and American Studies, University of Oldenburg. In 2016, he completed his doctoral studies in American literature at the University of Cologne. Greve has published articles on Cormac McCarthy, Mark Z. Danielewski, critical theory, and speculative realism, and he is the co-editor of America and the Musical Unconscious (Atropos, 2015) and Superpositions: Laruelle and the Humanities (Rowman \& Littlefield International, 2017). His book Shreds of Matter: Cormac McCarthy and the Concept of Nature will be published with Dartmouth College Press.

\section{MARKUS WIERSCHEM}

Markus Wierschem studied Philosophy, German, Media Studies, and English and American Literary and Cultural Studies at the University of Paderborn and St. Olaf College (Northfield, MN). In 2017, he received his doctorate degree for his dissertation An American Apocalypse? Myth, Violence, and Entropy in the Novels of Cormac McCarthy (MSU Press, forthcoming 2019). He is the author of numerous articles and has edited the anthology Patterns of Dis/Order: Beiträge zur Kulturgeschichte der Unordnung (LIT: 2017), as well as America(n) Matters: Selected Essays in American Studies (Winter: forthcoming 2018). He has been teaching courses on various topics of American Literature and Culture as well as the didactics of English at the University of Paderborn since 2011. 